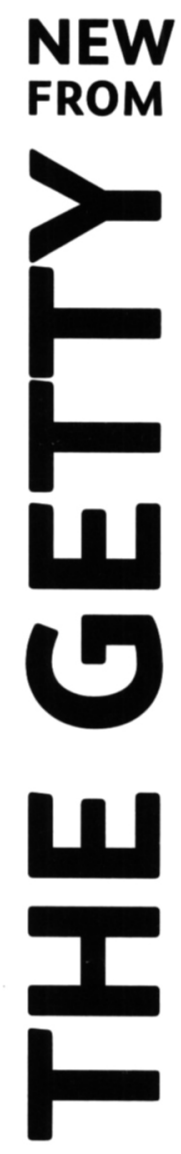

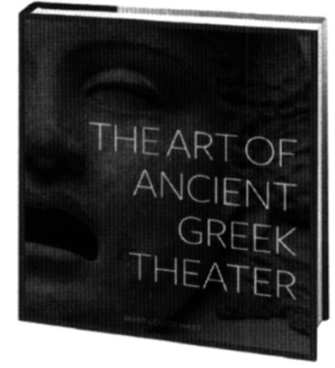

The Art of

Ancient Greek Theater

Edited by Mary Louise Hart

The origins of tragedy and comedy, as well as evidence of many plays that have been lost to history, are revealed through classical Greek painting and sculpture.

\section{£35.00 Hardcover}

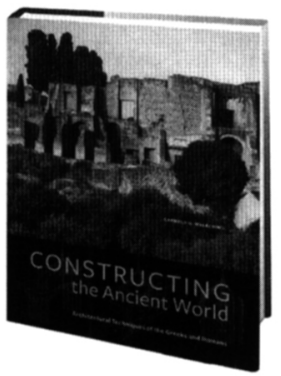

\section{Constructing the Ancient World}

Architectural Techniques of the Greeks and Romans Carmelo G. Malacrino

Lavishly illustrated, this fascinating book provides an overview of the evolution of methods and materials employed in Greek and Roman architecture from the third century B.C. through the fifth century A.D.

£35.00 Hardcover

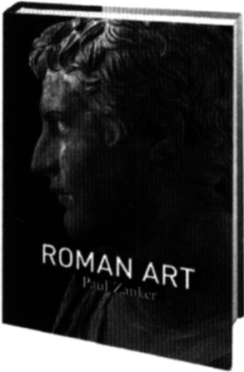

\section{Roman Art}

Paul Zanker

The evolution of Roman imagery is placed in the political and social context of Republican Rome and the Empire in this groundbreaking study.

$\mathbf{£ 4 0 . 0 0}$ Hardcover

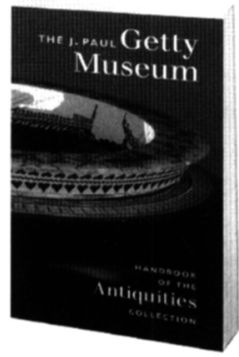

The J. Paul Getty Museum Handbook of the Antiquities Collection Revised Edition

Edited by Kenneth Lapatin and Karol Wight

This guide showcases monumental marble sculptures, Greek and Roman gems, and Hellenistic silverware, jewelry, and glass in the J. Paul Getty Museum's collection.

£13.99 Paperback 


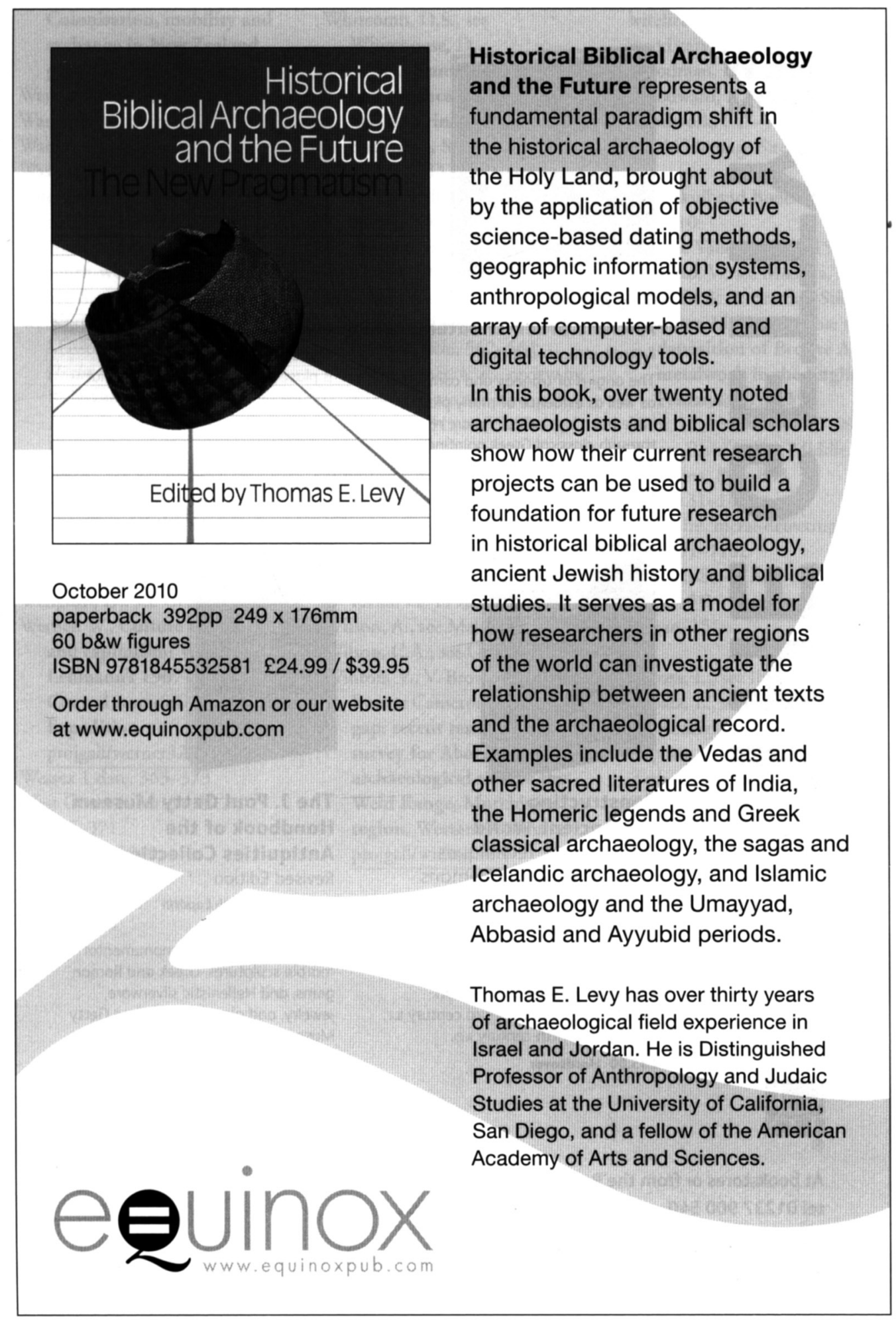




\section{Contact Details}

\section{AntIQUITY 2011 Subscription Order Form}

Name:

Delivery Address (include post/zip code and country)

Telephone:

Fax

Email:

Premium: printed and online version of the journal AND access to the electronic archive of previous issues back to 1927

Combined: printed and current online versions of the journal

Print only: printed version of the journal

Online only: online current version of the journal

\section{Journal Subscription}

\begin{tabular}{|l|c|c|c|c|c|c|c|c|c|c|}
\hline \multirow{2}{*}{2011} & \multicolumn{5}{|c|}{ Institutional } & \multicolumn{5}{c|}{ Individual } \\
\cline { 2 - 13 } & Tick box & UK $£$ & VAT (see note) & US $\$$ & $£$ & Tick box & UK $£$ & VAT (see note) & US $\$$ & $£$ \\
\hline Premium & $\square$ & 324 & (+£40.27 VAT) & 546 & 439 & $\square$ & 77 & (+£7.21 VAT) & 143 & 111 \\
\hline Combined & $\square$ & 182 & $(+£ 15.42$ VAT) & 305 & 242 & $\square$ & 61 & (+£4.41 VAT) & 113 & 89 \\
\hline Print only & $\square$ & 163 & $n / a$ & 172 & 215 & $\square$ & 54 & n/a & 102 & 84 \\
\hline Online only & $\square$ & 153 & (+£26.78 VAT) & 259 & 210 & $\square$ & 38 & (+£6.65 VAT) & 72 & 57 \\
\hline For airmail delivery add & $\square$ & 23.30 & & 40 & 25 & $\square$ & 23.30 & & 40 & 25 \\
\hline
\end{tabular}

Note: VAT will be due on the online element of subscriptions from the UK and from non-registered subscribers elsewhere in the EU.

EU customers should provide their VAT number:

\section{Method of Payment}

One off payment for 2011 only by Credit Card

$\square$ Continuous annual payment by Credit Card
Card: Visa / MasterCard / Eurocard / Switch / Connect

Card No:

Valid from:

Expiry Date

Issue No:

Card holder's name (as it appears on card)

Card holder's address (if different to delivery)

Signature Date

Cheque or postal order

Please make cheque payable to Portland Customer Services.

Bank Transfer

Make payment to Portland Customer Services, NatWest Bank PIc, 25 High Street, Colchester CO1 1DG, UK. Account \# 01863630 - Sort Code: 60-06-06

Please include full name and reason for transfer i.e. Antiquity subscription and supply us with details of your transfer, date of transaction, amount and the bank from which you are transferring.

Direct Debit

Please send me a direct debit mandate form

Proforma Invoice

Please send me a proforma invoice

Discounts may be available for students and institutions in developing countries. Please apply to the Editor for details.

Please send form and payment to:

Portland Customer Services, Commerce Way, Colchester CO2 8HP, UK

Tel: +44 (0)1206 796351 Fax: +44(0)1206 799331

email: sales@portland-services.com www.portland-services.com 


\section{Notes for contributors}

Antiquity aims to report new archaeological research, method and issues of international significance in plain language to a broad academic and professional readership. The journal is published quarterly in March, June, September and December.

Submissions are invited in the following categories: Research (max. 5000 words), Method and Debate (each max. 3000 words). Word limits include all text, tables, references and figure captions.

Antiquity uses a secure and confidential online submission and peer-review system. Detailed help on how to submit is available both prior to submission and throughout the submission process. To submit a manuscript please visit our website at http://antiquity.ac.uk/contribute/ contribute.html where you will find a link to the submission site and full Instructions for authors.

Wherever possible manuscripts should be submitted as a single Adobe PDF document containing all text, tables and figures but excluding any covering letter. If you cannot submit your manuscript as a PDF, you may submit separate text and graphics files. If your paper is accepted for publication, you will be asked to provide separate high-resolution, publication-quality graphics, in TIFF or EPS format. It is therefore best for the initial submission to create any graphics using applications that are capable of preparing acceptable TIFF or EPS formats. Resolutions must be $300 \mathrm{dpi}$ or higher and image dimensions should be either half-page width $(65 \mathrm{~mm})$ or full-page width $(135 \mathrm{~mm})$. The maximum acceptable height is $185 \mathrm{~mm}$. Maps and plans must include an accurate scale and north point.

As part of the submission process authors will be required to confirm that the substance of the content presented has not been published previously and is not currently being considered for publication elsewhere.

We prefer to receive submissions in English but can consider submissions in French, German, Italian and Spanish where submitting in English is not possible. (Accepted papers are translated free of charge and published in, English.)

All submissions are considered by the Editor in the first instance. Suitable papers are peerreviewed by a minimum of two experts. If you are unsure whether a paper is suitable for Antiquity, please contact the Editor prior to submission (editor@antiquity.ac.uk).

\section{Project Gallery (http://antiquity.ac.uk/ projgall/)}

The Project Gallery (max. 1000 words +6 figures) is part of Antiquity's online Bulletin and is intended for the announcement, update or preliminary reports about projects and ideas of international status. The Project Gallery also welcomes contributions to archaeological historiography. Please note that the Editor will not accept reports about local or regional surveys, sites or artefacts unless of wider significance; articles of local and regional interest should be properly directed to the national records and journals of the country concerned. Project Gallery articles are not normally peerreviewed but the Editor may seek external advice.

\section{Books for review}

We welcome books for review on archaeology and associated research. Please send books to the Reviews Editor, Dr Madeleine Hummler, at Antiquity, King's Manor, York YO1 7EP, UK (reviews@antiquity.ac.uk). 


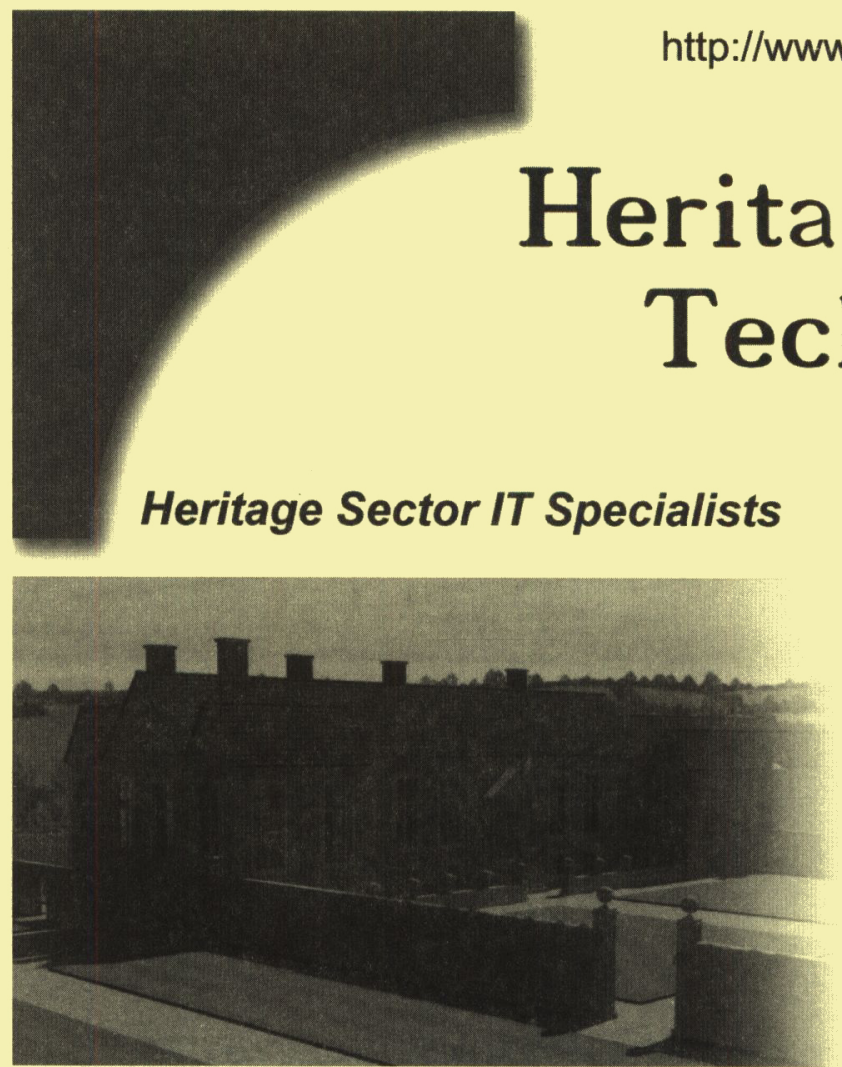

\section{D Visualisation \\ FDigital visualisation of objects, buildings \& landscapes \\ FPhoto-realistic, high quality historical reconstructions}

Services for visitor attractions, academia \& commercial projects

F Individually tailored to to fit all requirements \& budgets

$\Gamma$ Services also include web design \& digital archaeological support

Heritage Technology specialises in creating highly realistic 3D visualisations from historical \& archaeological data. Digital reconstruction is a proven technique in both academic \& commercial archaeology for portraying often complex spatial \& temporal data in an accessible and engaging way. Explore the possibilities at: 


\title{
Archaeopress
}

Gordon House, 276 Banbury Road, Oxford OX2 7ED England Tel/Fax: +44 1865311914

e-mail: bar@archaeopress.çom http: //www.archaeopress.com

\author{
B.A.R. \\ British Archaeological Reports
}

BAR -52132, 2010 The Gllund Project: Excavations in Regional Context Proceedings of the 19th Meeting of the European Association of South Asian Archoeology in Ravenna, Itoly, July 2007 edited by Teresa P. Raczek and Vasant Shinde. ISBN $9781407306735 . \pm 25.00$.

BAR -S2133, 2010 South Asian Archaeology 2007 Proceedings of the 19th Meeting of the European Association of South Asian Archaeology in Ravenna, Italy, July 2007. Volume II: Historic Periods edited by Pierfrancesco Callieri and Luca Colliva. ISBN 9781407306742. f56.00.

BAR -\$2134, 2010 De Pesues a Pejanda: Arqueologia de la Cuenca del Nansa (Cantabria, Espafia), E. Muñoz Fernández, J. Ruiz Cobo (Directores). ISBN 9781407306759 . $£ 55.00$.

BAR -S2135, 2010 Sargonic and Presarzonic Texts in The World Museum Liverpool by Eric L. Cripps. ISBN $9781407306766 . \mathrm{f3}^{2} .00$.

BAR -S2136, 2010 Anclent and Modern Bone Artefacts from Amerlca to Russia Cultural, technological and functional signature edited by Alexandra Legrand-Pineau, Isabelle Sidera, Natacha Buc, Eva David and Vivian Scheinsohn with the collaboration of Douglas V. Campana, Alice M. Choyke, Pam Crabtree and Elisabeth A. Stone. ISBN $9781407306773 . £ 53.00$

BAR - 52137,2010 Die Funktion und Bedeutung der Reiter-und Pferdeführerdarstellungen auf attischen Grab- und Weihreliefs des 5. und 4. Jhs. $v$. Chr. by Angelos Tillios. ISBN 978140730678 0. E36.00.

BAR -S2138, 2010 Anthropomorphic and Zoomorphic Miniature Figures in Eurasla, Africa and Meso-America Morphology, materiality, technology, function and context edited by Dragos Gheorghiu and Ann Cyphers. ISBN 978140730679 7. £35.00.

BAR - 2139,2010 Pastoralists, Warrlors and Colonists: The Archaeology of Southern Madagascar by Mike Parker Pearson with Karen Godden, Ramilisonina, Retsihisatse, Jean-Luc Schwenninger, Georges Heurtebize, Chantal Radimilahy and Helen Smith with contributions by Irene de Luis, David Barker, Seth Priestman, Lucien Rakotozafy, Bako Rasoarifetra, Alan Vince', Zoë Crossland and Brian Boyd. ISBN 9781407306803 . £95.00.

BAR -S2140, 2010 Plthol Technology and history of storage vessels through the ages by Mimika Giannopoulou. ISBN 9781407306810. f60.00.

BAR -52141, 2010 Pharmacy and Medicine In Ancient Egypt Proceedings of the conferences held in Cairo (2007) and Manchester (2008) edited by Jenefer Cockitt and Rosalie David. ISBN $9781407306827 . £ 34.00$

BAR -52142, 2010 Prehistoric Sri Lanka Late Pleistocene rockshelters and an open-air site by Halawathage Nimal Perera. ISBN 97814073 0683 4 $£ 52.00$

BAR -52143, 2010 A Comparison of the Late Pleistocene and Early Holocene Burlals of North Africa and Western Europe Grim Investigations: Reaping the Dead by Emma Elder. ISBN 9781407306841 1. £48.00.

BAR -S2144, 2010 The Lake of Knlves and the Lake of Fire Studies in the topography of passage in ancient Egvptian religious literature by Eltayeb Sayed Abbas. ISBN 9781407306858 . $£ 30.00$

BAR - $\$ 2145,2010$ Ritual Practice between the Late Bronze Age and Protogeometric Periods of Greece by Gemma Marakas. ISBN 978140730686 5. $£ 35.00$.

BAR - S2146, 2010 The Relief Plaques of Eastem Eurasia and China The 'Ordos Bronzes', Peter the Great's Treasure, and their kin by John Boardman. Beazley Archive Occasional Paper. ISBN 978140730687 2. $£ 48.00$.

BAR -S2147, 2010 Conservation Approaches to Earthen Architecture in Archaeological Contexts by Louise Cooke. ISBN $9781407306889 . \pm 58.00$.

BAR - 52148,2010 El Comercio de Terra Siglliata altoimperial en el Circulo del Estrecho Balance historiográfico y líneas de investigación by Macarena Bustamante Álvarez. ISBN $9781407306896 . £ 47.00$.

BAR -52149, 2010 Traditional Weapons of Africa (BIllhooks, SIckles and Scythes) Regional approach and technical, morphological and aesthetic classification by Tristan Arbousse Bastide ISBN 978140730690 2. £33.00.

BAR -\$2150, 2010 Ideologla y realidad en las primeras socledades sedentarlas (1400 ANE-350 DNE) de la cuenca norte del Titicaca, Perú by Henry Tantaleán. ISBN 9781407306919 . £65.00.

BAR -52151, 2010 Unks between Megalithism and Hypogeism in Western Mediterranean Europe edited by Juan Antonio Cámara Serrano, José Andrés Afonso Marrero and Liliana Spanedda. ISBN 978140730692 6. £41.00.

BAR - $\$ 2152,2010$ Crossing the Stralts: Prehistoric Obsidlan Source Exploitation in the North Pacific Rim edited by Yaroslav V. Kuzmin and Michael D. Glascock. ISBN 978140730694 0. £42.00.

BAR - 52153, 2010 Stewards and Stakeholders of the Archaeological Record: Archaeologists, Folklore and Burial Mounds in Agder, Southern Norway by Atle Omland. ISBN 978140730695 7. £46.00.

BAR -S2154, 2010 A Circumpolar Reappraisal: The Legacy of Gutorm Gjessing (1906-1979) Proceedings of an International Conference held in Trondheim, Norway, 10th-12th October 2008, arranged by the Institute of Archaeology and Religious Studies, and the SAK department of the Museum of Natural History and Archaeology of the Norwegian University of Science and Technology (NTNU) edited by Christer Westerdahl. ISBN 9781407306964 4. £66.00.

BAR -S2155, 2010 El Paleolftico Inferior en la Meseta Norte, Espafia: Sierra de Atapuerca, La Maya, El Basalito, San Quirce y Ambrona Estudio tecnológico y experimental by Marcos Terradillos Bernal. ISBN 978140730697 1. £64.00.

BAR -\$2156, 2010 Typologle des armatures Itthiques gravettiennes de la grotte d'Isturitz (Pyrénées-Atlantlques, France) by Aurélien Simonet. ISBN 978140730698 8. $£ 42.00$.

BAR -52157, 2010 North Sea and Channel Connectivlty during the Late Iron Age and Roman Period (175/150 BC-AD 409) by Francis M. Morris. ISBN 978140730699 5. $£ 44.00$.

See all Archaeopress books, with short summaries, at: www.archaeopress.com

BAR titles can be ordered from Hadrian Books, 122 Banbury Road, Oxford OX2 7BP, UK

www. hadrianbooks.co.uk 